\title{
Statistical analyses of the performance of Macedonian investment and pension funds
}

\author{
Petar Taleski ${ }^{1}$ and Vasko Bogdanovski ${ }^{2, *}$ \\ ${ }^{1}$ NLB Nov penziski fond Skopje, Euro College - Kumanovo, \\ 1000 Skopje, R. Macedonia \\ E-mail: 〈p.taleski@npf.com.mk〉 \\ ${ }^{2}$ NLB Nov penziski fond Skopje, \\ 1000 Skopje, R. Macedonia \\ E-mail: 〈v.bogdanovski@npf.com.mk〉
}

\begin{abstract}
The foundation of the post-modern portfolio theory is creating a portfolio based on a desired target return. This specifically applies to the performance of investment and pension funds that provide a rate of return meeting payment requirements from investment funds. A desired target return is the goal of an investment or pension fund. It is the primary benchmark used to measure performances, dynamic monitoring and evaluation of the risk-return ratio on investment funds. The analysis in this paper is based on monthly returns of Macedonian investment and pension funds (June 2011 - June 2014). Such analysis utilizes the basic, but highly informative statistical characteristic moments like skewness, kurtosis, Jarque-Bera, and Chebyishev's Inequality. The objective of this study is to perform a trough analysis, utilizing the above mentioned and other types of statistical techniques (Sharpe, Sortino, omega, upside potential, Calmar, Sterling) to draw relevant conclusions regarding the risks and characteristic moments in Macedonian investment and pension funds. Pension funds are the second largest segment of the financial system, and has great potential for further growth due to constant inflows from pension insurance. The importance of investment funds for the financial system in the Republic of Macedonia is still small, although openend investment funds have been the fastest growing segment of the financial system. Statistical analysis has shown that pension funds have delivered a significantly positive volatility-adjusted risk premium in the analyzed period more so than investment funds.
\end{abstract}

Key words: desired target return, downside deviation, risks, investments.

Received: September 30, 2014; accepted: October 6, 2015; available online: October 31, 2015

DOI: $10.17535 /$ crorr.2015.0030

\section{Introduction}

According to the Investment Funds Act and the Mandatory and Voluntary Capitally Financed Pension Insurance Act, the regulatory framework for the

${ }^{*}$ Corresponding author. 
analyzed funds has been established by the Securities and Exchange Commission in the Republic of Macedonia and the Agency for Supervision of Fully Funded Pension Insurance (MAPAS).

The Macedonian Securities and Exchange Commission is an autonomous and independent regulatory body with public bodies established by the Securities Act, the Investment Funds Act, the Joint Stock Companies Takeover Act and the associated by-laws. The Commission regulates and oversees securities operations in Macedonia. Within its legal powers and authorizations, the Commission provides for the legal and efficient functioning of the securities market as well as protection of the investor rights in order to strengthen permanently public trust in the institutions involved in the Macedonian securities market. [19]

MAPAS was established for supervising the operations of pension companies and pension funds with the purpose of protecting the interests of pension funds members (stakeholders). As a legal entity, the Agency is answerable to the Assembly of the Republic of Macedonia. The Agency is responsible for granting and withdrawing licenses for the establishment and management of pension companies. The Agency supervises operations of pension companies, pension funds, as well as custodians and foreign asset managers [12].

In order to minimize future crises, financial market stakeholders and regulators need to effectively determine the potential stress in a financial system. Therefore, the construction of economic and financial indicators that will provide timely warning of potential risks is very important for the prevention (minimizing) of financial crises.

Pension funds are the second largest segment of the financial system, which also has great potential for further growth based on constant inflows provided by pension insurance. Its significance for the financial stability is wide. As a part of financial assets of households pension funds are a significant debtor and creditor of the banking and other segments of the financial sector. Pension funds can serve as investors of deposits in domestic banks because of the ownership links between the companies that manage pension funds and some of the domestic banks. Reputational risk is therefore extremely important and difficult to measure. Government bonds have a predominant share in the total assets of pension funds. In 2013, amid generally low interest rates, and for the purpose of achieving better yields, fund management companies shifted part of their fund assets from debt (interest bearing) securities into equity securities. In this framework, an increase in investments in foreign investment funds (ETF) occurred, which are generally characterized by lower risk than that associated with investments by pension funds in stocks [13].

The importance of investment funds for the financial system in Macedonia is still small, although open-end investment funds were the fastest growing segment in the financial system in 2013 (according to the percentage increase, although the absolute increase was small). The share of assets owned by 
investment funds in the total assets of financial institutions has doubled, but continues to be minimal $0.2 \%$ [14].

\section{Review of literature}

Developing a performance measurement framework that is specific to investment and pension funds is a relatively new topic in literature. Portfolio evaluation has evolved dramatically over the last 40 years. The acceptance of modern portfolio theory has changed the evaluation process from crude return calculations to rather detailed explorations of risk and return, and the sources of each of these. Furthermore, 40 years ago, evaluation was not an integral part of many organizations. This has changed (in part from external pressure) so that at this time, most investment organizations incorporate evaluation as an integral part of their decision-making process [7].

In this paper, twelve measures have been proposed in literature to evaluate the performance of a funds, including the notions of return and risk. Each of them has its strengths, but also its weaknesses and limits. They encompass various dimensions that make sense for most of them. Hence, it would be unfair to say "one size fits it all". In our ongoing efforts, we endeavor to arbitrate between them and to distinguish those that can be considered generally as the most significant in order to explain portfolio performance but also persistence.

Performance evaluation refers to the process of measuring and interpreting the performance of an investment program. Performance evaluation delivers an informed look at past performance of investment "results with respect to the fund's investment objectives". A properly conducted, performance evaluation provides the plan containing valuable information concerning the strengths and weaknesses of the investment program and identifies areas of potentially profitable enhancements [8].

Underlying much of the recent policy debate is the increasing recognition that pension fund assets have important differences compared with other forms of collective investments. Pension funds have the objective of providing income replacement in retirement, whereas other forms of collective investments are primarily concerned with short-term wealth maximization. The differences in objectives stem from different time frames, over which performance is considered and different attitudes to risk. Despite these distinctions, the performance measures that are typically applied to pension funds are identical to those used to evaluate the performance of other types of investments [9]. 


\section{Methodology}

\subsection{Data description}

Statistical analyses of the investment and pension funds can serve to review the performances of the funds. Furthermore, statistical analysis can present a potential span of future incomes earned from investments in the assets of funds. To prepare this analysis, we use data for earnings of investment and pension funds using the value of their accounting units per month.

The analysis applied in this paper is conducted based on monthly returns of investment and pension funds in Macedonia (June 2011 - June 2014). This analysis should reveal ways of using statistics to analyze the success rate of investment and pension funds, possible interpretations of certain statistical measures related to risk analysis, and an appropriate presentation of certain characteristic points identified during the statistical analysis.

\subsection{Absolute risk measures}

Standard deviation measures show that dispersed returns lie around the average. A higher standard deviation indicates that returns are spread out over a larger range of values, making them more volatile [2].

At times, investors begin quantitative screening stating that they want a "low risk" fund. The link between risk and standard deviation in the world of traditional investments goes way back in history; thus they equate a high standard deviation with high risk and also use standard deviation as a comparative statistic, when the truth is that standard deviation is just a statistic that measures predictability.

A high standard deviation means that the fund is volatile, not that the fund is risky or will lose money, while a low standard deviation means a fund is generally consistent in producing similar returns. A fund can have extremely low standard deviation and lose money consistently, or have high standard deviation and never experience a losing period [6].

When it comes to comparing traditional return analysis and absolute return analysis, one of the differences between the two is accepting the fact that volatility is good, provided it is on the upside. By all means, upside volatility should be less of a concern for most investors, who should consider downside deviation a better measure of a fund's ability to achieve its return goal. Therefore, investors should acquaint themselves with downside deviation. Downside deviation introduces the concept of minimum acceptable return (MAR) as a risk factor. Downside deviation is a modification of the standard deviation such that only a variation below a minimum acceptable return is 
considered. The minimum acceptable return can be chosen to match specific investment objectives [15].

$$
\text { Downside deviation }=\frac{\sqrt{\sum_{i=1}^{n}\left(M I N\left(R_{i}-M A R, 0\right)\right)}}{N}
$$

However, to determine if the layout of analyzed returns has a distribution that is close to the shape of a normal distribution, a statistical test for normality of the distribution shape should be conducted. The test helps in determining the possibility of whether the expected future returns of accounting units in investment and pension funds will be within the framework of the normal layout of returns.

The Jarque - Bera test (hereinafter referred to as JB test) as a test for normality of the distributions shape determines whether the distribution of returns by individual classes of instruments has a normal distribution or not. The value of the JB test with a significance level of 0.10 (confidence level of $90 \%$ ) must not be greater than 9.21, while a significance level of 0.05 (confidence level of 95\%) must not be greater than 5.99. The significance level of 0.05 is used more frequently [10].

$$
\text { Test } \mathrm{JB}=\left(\frac{N}{6}\right) *\left[\text { coefficient of skewness }{ }^{2}+\frac{\text { coefficient of } \text { kurtosis }^{2}}{4}\right]
$$

That would be the case if we base the assumptions on standard normal layout. Considering that in this case, we do not have a standard normal layout, we can apply the equation of Chebyishev's Inequality, which states that in any set of observations, whether the shape of the distribution has a normal layout or not, the percentage of observations that lies within $\mathrm{k}$ standard deviations is $1-1 / k^{\wedge} 2$ for each $k>1$. In the case of a 2 standard deviation, the range in $75 \%$ of the cases is around the arithmetic mean or the expected return. In the case of 3 standard deviations, this is true for $89 \%$ of the cases [17].

In order to determine how much the data deviates from the so-called normal layout, the moments of dispersion are calculated. The program package MS Excel calculates the coefficient of skewness and the coefficient of kurtosis according to equation (1) and (2) [5].

$$
\begin{gathered}
\text { Adjusted skewness }=\frac{n}{(n-1)(n-2)} * \frac{\sum_{i=1}^{n}\left(x_{i}-\bar{x}\right)^{3}}{\left(s^{2}\right)^{3 / 2}} \\
\text { Adjusted kurtosis }=\frac{n(n+1)}{(n-1)(n-2)(n-3)} \sum_{i=0}^{n}\left(\frac{x_{i}-\bar{x}}{s}\right)^{4}-\frac{3(n-1)^{2}}{(n-2)(n-3)}
\end{gathered}
$$

When returns fall outside of a normal distribution, the distribution exhibits skewness or kurtosis. Skewness is known as the third "moment" and kurtosis the "fourth" moment of a return distribution, where the mean and the variance are 
the first and second moments, respectively (variance is a statistic that is closely related to standard deviation, where both measure the dispersion of an investment's historical returns). Ideally, investors should consider all four moments or characteristics of the return distribution of an investment.

- Skewness: This measure characterizes the degree of asymmetry of a distribution around its mean. Positive skewness indicates a distribution with an asymmetric tail extending toward more positive values. Negative skewness indicates a distribution with an asymmetric tail extending toward more negative values.

- Kurtosis: kurtosis measures the degree to which a distribution is more or less peaked than a normal distribution. Positive kurtosis indicates a relatively peaked distribution. Negative kurtosis indicates a relatively flat distribution. A normal distribution has a kurtosis of 3. Therefore, an investment characterized by high kurtosis will have "fat tails" (higher frequencies of outcomes) at the extreme negative and positive ends of the distribution curve. A distribution of returns exhibiting high kurtosis tends to overestimate the probability of achieving a mean return. Skewness and kurtosis are important because few investment returns are normally distributed. Investors often predict future returns based on standard deviation, but such predictions assume a normal distribution. An investment's skewness and kurtosis measure how its distribution differs from a normal distribution and therefore provide an indication of the reliability of predictions based on standard deviation.

\begin{tabular}{|c|c|c|c|c|}
\hline \multicolumn{5}{|c|}{ Return Distribution Characteristics } \\
\hline Name & Moment & Common Name & Characteristics & Preference \\
\hline $\begin{array}{c}\text { Standard } \\
\text { deviation } \\
\text { (variance) }\end{array}$ & Second & Volatility & $\begin{array}{c}\text { Balance point of } \\
\text { the area under } \\
\text { the distribution }\end{array}$ & $\begin{array}{c}\text { Higher values with } \\
\text { higher moments } \\
\text { constant }\end{array}$ \\
\hline Skewnest & Third & Fat tail & $\begin{array}{c}\text { Measure of } \\
\text { symmetry }\end{array}$ & $\begin{array}{c}\text { Lowest value to } \\
\text { meet requirement }\end{array}$ \\
\hline Kurtosis & Fourth & Fat tail & Measure of shape & $\begin{array}{c}\text { Negative downside, } \\
\text { positive upside } \\
\text { (Kurtosis for normal } \\
\text { distribution is 3) }\end{array}$ \\
\hline
\end{tabular}

Table 1: Return distribution characteristics

\subsection{Absolute risk-adjusted measures}

When it comes to comparing traditional return analysis and absolute return analysis, one of the differences between the two is accepting the fact that 
volatility is good, provided it is on the upside. By all means, upside volatility should be less of a concern for most investors, who should consider downside deviation as a better measure of a fund's ability to achieve its return goal. Therefore, investors should acquaint themselves with downside deviation. Downside deviation introduces the concept of minimum acceptable return (MAR) as a risk factor. The question is, what statistics can we use to compare funds, if we take the standard deviation out of the equation? While fund returns may seem useful, they do not consider the investment's risk, which is why investors should always use risk-adjusted statistics such as the Sharpe, Sortino, Sterling or Calmar ratios [18].

The Sharpe ratio is the best-known risk-adjusted statistic. An investment's Sharpe ratio can be calculated by taking the average period return, subtracting the risk-free rate, and dividing it by the standard deviation for the period [1].

$$
\text { Sharpe Ratio }=\frac{\text { Mean-Risk Free Rate }}{\text { Standard Deviation }(\sigma)}
$$

Since upside volatility will decrease the Sharpe ratio of some investments, the Sortino ratio can be used as an alternative. The Sortino ratio is similar to the Sharpe ratio; however, it uses downside deviation instead of standard deviation in the denominator of the formula, as well as substituting a minimum acceptable return for the risk free rate. In other words, the Sortino ratio equals the return minus the MAR, divided by the downside deviation [11].

$$
\text { Sortino Ratio }=\frac{\text { Mean }- \text { Minimum Acceptable Return }(M A R)}{\text { Downside Deviation } \sigma}
$$

The omega ratio is a relative measure of the likelihood of achieving a given return, such as a minimum acceptable return (MAR) or a target return. The probability that a given return will be met or exceeded is greater when the omega value is higher. Omega represents the ratio of the cumulative probability of an investment's outcome exceeding an investor's defined return level (a threshold level), to the cumulative probability of an investment's outcome being below an investor's threshold level. The omega concept divides expected returns into two parts - gains and losses, or returns above the expected rate (the upside) and those below it (the downside). Therefore, in simple terms, consider omega as the ratio of upside returns (good) relative to downside returns (bad).

where

$$
\Omega=\frac{\int_{r}^{b}(1-F(x)) d x}{\int_{a}^{r} F(x) d x}
$$

$\mathrm{r}$ is the threshold return, and

$\mathrm{F}$ is cumulative density function of returns [4]. 
There are several ways to estimate the risk of not achieving a given return, but most of them assume that returns are normally distributed. However, as stated above, investment returns are not normally distributed, as they tend to be skewed or "fat-tailed" (i.e., there are more extreme returns than implied by the theoretical normal distribution). The omega calculations are important as they use the actual return distribution rather than a theoretical normal distribution. Thereby the omega ratio and its components more accurately reflect the historical experience of the investment being measured.

Since omega considers all information available from an investment's historical return data, it can be used to rank potential investments in a manner specific to the investor's threshold level. However, the omega decisions are variable for at least two reasons:

- As return information is updated, the probability distribution will change and omega must be updated.

- As an investor's threshold level changes, the rankings among comparative investments may change.

Consequently, omega allows investors to visualize the trade-off between risk and return at different threshold levels for various investment choices. Note that the omega ratio equals 1 when the threshold is set to the mean of the distribution.

The omega ratio is a useful investment tool because it can be used in a compact way to show how different investment options relate to a target return and to a MAR.

Because the Sharpe ratio is calculated from return data that has been averaged or annualized, the resulting ranking of the investments do not include higher levels of information specific to the shape of the distribution of the underlying return data. As a result, it is reasonable to conclude that the observed differences in rankings are due to the higher levels of information contained in the omega calculations. In effect, omega as a risk-adjusted measure provides investors with additional information to acquire a better understanding of the risk/reward characteristics encapsulated within an investment's historic returns.

Drawdown analysis can be an excellent way to screen investments. A Maximum Drawdown is the maximum amount of loss from an equity high through the drawdown and back to the point the equity high is reached again. There could be many drawdowns over a given date range and they are listed starting with the maximum drawdown.

The reasons for a drawdown can be numerous, from market stress, giving back part of unrealized profits after a large increase in equity, or just due to poor trading. From a quantitative perspective, though, it is important to 
analyze the reasons that caused a particular drawdown, and not exclude a fund based on just absolute numbers [3].

\section{Results}

The foundation of the post-modern portfolio theory is creating a portfolio based on the desired target return. This specifically applies to the operations of investment and pension funds in order to provide a rate of return that meets payment requirements from the investors of funds. The preferred targeted return is a return necessary for achieving the desired goal of the investment or pension fund. It is the primary benchmark used to measure performances, dynamic monitoring and evaluation of the risk - return ratio on investment of funds.

The following table presents a number of positive and negative returns from the accounting units of funds, and their positive and negative average values.

\begin{tabular}{|c|c|c|c|c|c|}
\hline & Fund name & $\begin{array}{c}\mathrm{Nr} \text { of } \\
\text { negative } \\
\text { returns }\end{array}$ & $\begin{array}{c}\text { Average value } \\
\text { of negative } \\
\text { returns }\end{array}$ & $\begin{array}{l}\mathrm{Nr} \text { of } \\
\text { positive } \\
\text { returns }\end{array}$ & $\begin{array}{c}\text { Average value } \\
\text { of positive } \\
\text { returns }\end{array}$ \\
\hline 1 & Ilirika Global & 17 & $-3.45 \%$ & 19 & $1.95 \%$ \\
\hline 2 & $\begin{array}{c}\text { Ilirika } \\
\text { Southeast } \\
\text { Europe } \\
\end{array}$ & 23 & $-3.08 \%$ & 13 & $2.30 \%$ \\
\hline 3 & $\begin{array}{c}\text { Innovo Status } \\
\text { Akcii }\end{array}$ & 23 & $-2.23 \%$ & 13 & $2.07 \%$ \\
\hline 4 & $\begin{array}{l}\text { KB Voluntary } \\
\text { Pension Fund }\end{array}$ & 12 & $-0.65 \%$ & 24 & $0.80 \%$ \\
\hline 5 & $\begin{array}{l}\text { KB Mandatory } \\
\text { Pension Fund }\end{array}$ & 11 & $-0.99 \%$ & 25 & $0.92 \%$ \\
\hline 6 & $\begin{array}{c}\text { KB Publikum } \\
\text { - Balanced }\end{array}$ & 17 & $-1.81 \%$ & 19 & $1.50 \%$ \\
\hline 7 & $\begin{array}{c}\text { KB Publikum } \\
\text { - Bonds }\end{array}$ & 15 & $-0.46 \%$ & 21 & $0.84 \%$ \\
\hline 8 & KD BRIC & 18 & $-3.26 \%$ & 18 & $2.48 \%$ \\
\hline 9 & $\begin{array}{c}\text { KD South } \\
\text { Balkan }\end{array}$ & 22 & $-2.22 \%$ & 14 & $2.14 \%$ \\
\hline 10 & $\begin{array}{c}\text { NLB Penzija } \\
\text { plus }\end{array}$ & 13 & $-0.74 \%$ & 23 & $0.91 \%$ \\
\hline 11 & $\begin{array}{c}\text { NLB Nov } \\
\text { Penziski Fond }\end{array}$ & 11 & $-0.79 \%$ & 25 & $0.88 \%$ \\
\hline
\end{tabular}

Table 2: Number of positive and negative returns from the accounting units of the funds, and their positive and negative average values (June 2011 - June 2014) 
The funds with the largest number of positive returns are KB Mandatory Pension Fund and NLB Nov Penziski Fond, while the funds with the lowest number of positive returns are Ilirika Southeast Europe and Innovo Status Akcii. The fund with the leading average value of positive returns is KD BRIC, while the fund with the lowest average value of positive returns is $\mathrm{KB}$ Voluntary Pension Fund.

The funds with the biggest number of negative returns are Ilirika Southeast Europe and Innovo Status Akcii, while the funds with the lowest number of negative returns are KB Mandatory Pension Fund and NLB Nov Penziski Fond. The fund with the largest average value of negative returns is Ilirika Global, while the fund with the lowest average value of negative returns is $\mathrm{KB}$ Publikum - Bonds.

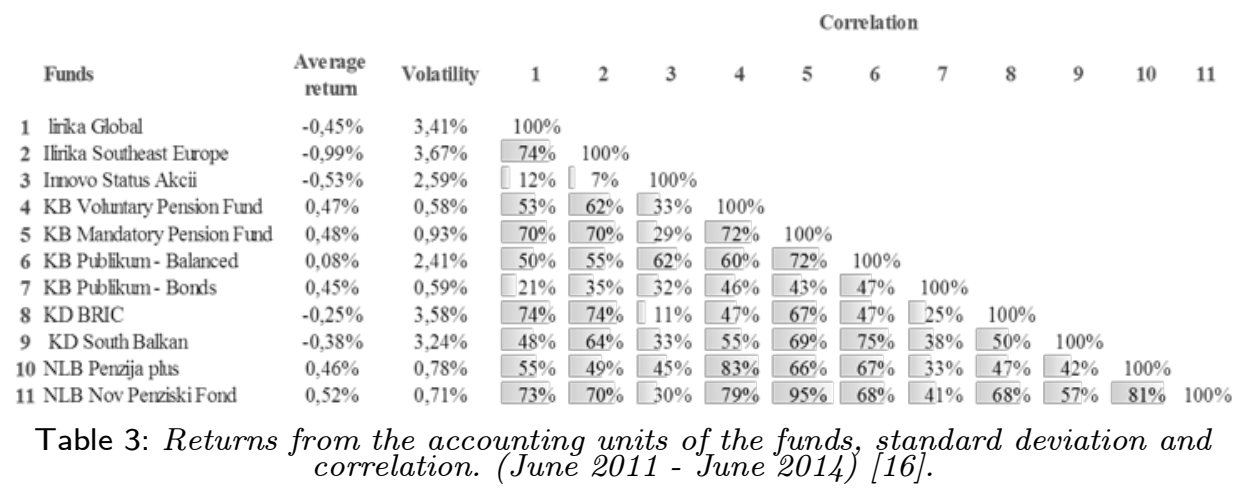

Table 3 presents the expected returns, the volatility of returns and the correlation among the selected accounting units of the investment and pension funds. The correlation coefficients from returns of pension funds have an outstanding positive value.

\begin{tabular}{|c|c|c|c|c|c|c|c|c|c|c|c|}
\hline \multirow{2}{*}{$\begin{array}{c}\text { Downside } \\
\text { Deviation }\end{array}$} & $\begin{array}{c}\text { Ilirika } \\
\text { Global }\end{array}$ & $\begin{array}{c}\text { Ilirika } \\
\text { Southeast } \\
\text { Europe }\end{array}$ & $\begin{array}{c}\text { Knnovo } \\
\text { Status }\end{array}$ & $\begin{array}{c}\text { Voluntary } \\
\text { Pension } \\
\text { Fund }\end{array}$ & $\begin{array}{c}\text { Mandatory } \\
\text { Pension } \\
\text { Fund }\end{array}$ & $\begin{array}{c}\text { KB } \\
\text { Publikum } \\
\text { Balanced }\end{array}$ & $\begin{array}{c}\text { KB } \\
\text { Publikum } \\
\text { Bonds }\end{array}$ & $\begin{array}{c}\text { KD } \\
\text { BRIC }\end{array}$ & $\begin{array}{c}\text { KLB } \\
\text { South } \\
\text { Balkan }\end{array}$ & $\begin{array}{c}\text { NLB } \\
\text { Penzija } \\
\text { plus }\end{array}$ & $\begin{array}{c}\text { Nov } \\
\text { Penziski } \\
\text { Fond }\end{array}$ \\
\cline { 2 - 11 } & $2.90 \%$ & $3.09 \%$ & $1.37 \%$ & $0.35 \%$ & $0.65 \%$ & $2.00 \%$ & $0.35 \%$ & $2.37 \%$ & $2.82 \%$ & $0.38 \%$ & $0.36 \%$ \\
\hline
\end{tabular}

Table 4: Downside deviation for the returns of accounting units of funds. (June 2011 - June 2014)

As is evident, Table 4 shows that investment funds are more volatile than pension funds in the analyzed period. 


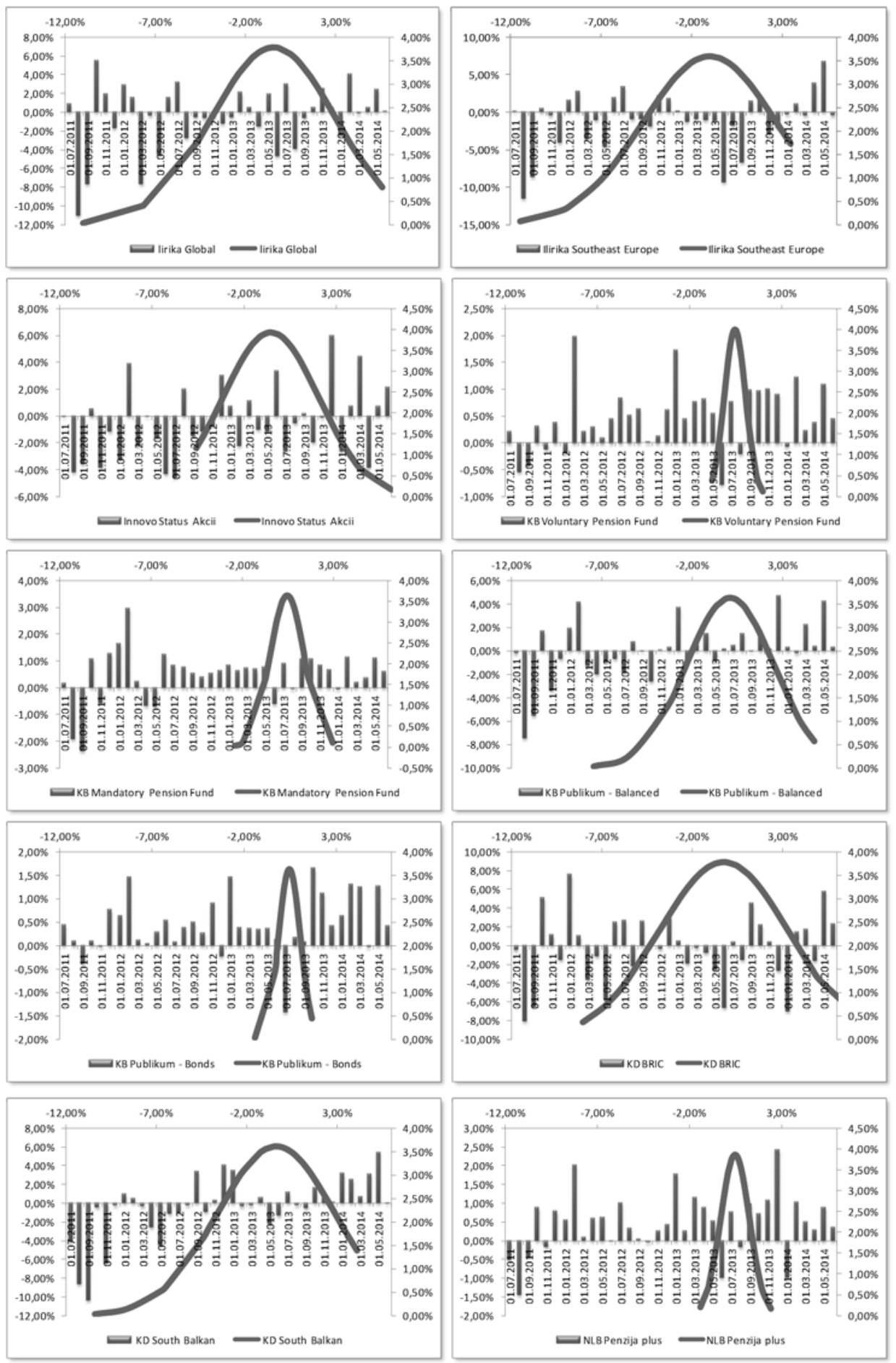




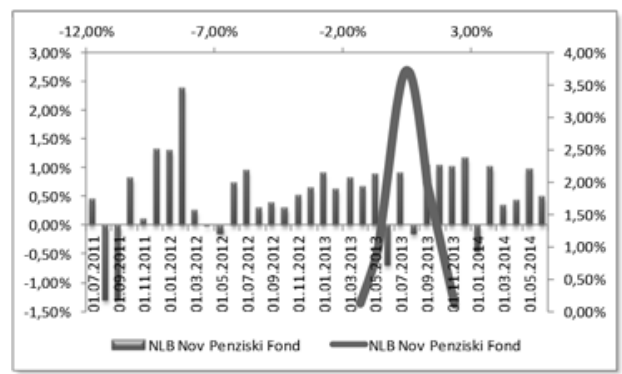

Figure 1-11: Distribution of returns of the accounting units of investment and pension funds.

\begin{tabular}{|c|c|c|c|c|c|c|c|c|c|c|c|}
\hline \multirow[t]{2}{*}{$\begin{array}{l}\text { JB } \\
\text { test }\end{array}$} & $\begin{array}{l}\text { Ilirika } \\
\text { Global }\end{array}$ & $\begin{array}{l}\text { Ilirika } \\
\text { Southeast } \\
\text { Europe }\end{array}$ & $\begin{array}{l}\text { Innovo } \\
\text { Status }\end{array}$ & \begin{tabular}{|c|} 
KB \\
Voluntary \\
Pension \\
Fund \\
\end{tabular} & \begin{tabular}{|c|} 
KB \\
Mandatory \\
Pension \\
Fund \\
\end{tabular} & $\begin{array}{c}\text { KB } \\
\text { Publikum } \\
\text { Balanced }\end{array}$ & $\begin{array}{c}\text { KB } \\
\text { Publikum } \\
\text { Bonds }\end{array}$ & \begin{tabular}{|c} 
KD \\
BRIC
\end{tabular} & $\begin{array}{c}\text { KD } \\
\text { South } \\
\text { Balkan }\end{array}$ & $\begin{array}{l}\text { NLB } \\
\text { Penzija } \\
\text { plus }\end{array}$ & \begin{tabular}{|c|} 
NLB \\
Nov \\
Penziski \\
Fond \\
\end{tabular} \\
\hline & 246 & & 761 & 1.202 & 16.883 & 9.958 & 4.896 & 0.353 & 16.295 & 1.230 & 6.972 \\
\hline
\end{tabular}

Table 5: The Jarque Bera test for normal distribution of returns from the accounting units of investment and pension funds

As can be seen in Table 5, the JB test with significance level of 0.10 meets the layout returns at Ilirika Southeast Europe, Innovo Status Akcii, KB Voluntary Pension Fund, KB Publikum - Bonds, KD BRIC, NLB Penzija plus, NLB Nov Penziski Fond. Therefore relevant conclusions about the layout of future returns by generating a span of possible expectations of returns using standard deviation as a measure of mathematical prediction can be expected in the said investment and pension funds. For returns from the funds Ilirika Global, KB Mandatory Pension Fund, KB Publikum - Balanced, KD South Balkan, mathematical measures for predicting using standard deviation should be approached with caution.

To predict future returns, we can generate a range of probabilities using standard deviation as a mathematical measure for predictions of returns and to appropriately generate the possible span of expected returns from the accounting units of the investment and pension funds.

\begin{tabular}{|c|c|c|c|c|c|c|c|c|c|c|c|}
\hline & $\begin{array}{l}\text { Ilirika } \\
\text { Global }\end{array}$ & $\begin{array}{c}\text { Пlirika } \\
\text { Southeast } \\
\text { Europe }\end{array}$ & $\begin{array}{c}\text { Innovo } \\
\text { Status } \\
\text { Akcii }\end{array}$ & \begin{tabular}{|c|} 
KB \\
Voluntary \\
Pension \\
Fund \\
\end{tabular} & \begin{tabular}{|c|} 
KB \\
Mandatory \\
Pension \\
Fund \\
\end{tabular} & $\begin{array}{c}\text { KB } \\
\text { Publikum } \\
\text { Balanced }\end{array}$ & $\begin{array}{c}\text { KB } \\
\text { Publikum } \\
\text { Bonds }\end{array}$ & KD BRIC & $\begin{array}{l}\text { KD South } \\
\text { Balkan }\end{array}$ & $\begin{array}{l}\text { NLB } \\
\text { Penzija } \\
\text { plus }\end{array}$ & $\begin{array}{c}\text { NLB Nov } \\
\text { Penziski } \\
\text { Fond }\end{array}$ \\
\hline \multicolumn{12}{|c|}{ DEV +} \\
\hline $68.26 \%$ & $2.97 \%$ & $2.69 \%$ & $2.06 \%$ & $1.04 \%$ & $1.41 \%$ & $2.49 \%$ & $1.04 \%$ & $3.34 \%$ & $2.86 \%$ & $1.24 \%$ & $1.23 \%$ \\
\hline $95.44 \%$ & $6.38 \%$ & $6.36 \%$ & $4.64 \%$ & $1.62 \%$ & $2.35 \%$ & $4.89 \%$ & $1.63 \%$ & $6.92 \%$ & $6.09 \%$ & $2.02 \%$ & $1.93 \%$ \\
\hline $99.74 \%$ & $9.80 \%$ & $10.03 \%$ & $7.23 \%$ & $2.19 \%$ & $3.28 \%$ & 7.30 & $2.22 \%$ & $10.51 \%$ & $9.33 \%$ & $2.80 \%$ & $2.64 \%$ \\
\hline \multicolumn{12}{|c|}{ DEV -} \\
\hline $68.26 \%$ & $-3.86 \%$ & $-4.66 \%$ & $-3.12 \%$ & $-0.11 \%$ & $-0.45 \%$ & $-2.33 \%$ & $-0.15 \%$ & $-3.83 \%$ & $-3.62 \%$ & $-0.32 \%$ & $-0.19 \%$ \\
\hline $95.44 \%$ & $-7.28 \%$ & $-8.34 \%$ & $-5.71 \%$ & $-0.69 \%$ & $-1.39 \%$ & $-4.37 \%$ & $-0.74 \%$ & $-7.42 \%$ & $-6.85 \%$ & $-1.10 \%$ & $-0.90 \%$ \\
\hline $99.74 \%$ & $-10.69 \%$ & $-12.01 \%$ & $-8.29 \%$ & $-1.26 \%$ & $-2.32 \%$ & $-7.14 \%$ & $-1.33 \%$ & $-11.00 \%$ & $-10.09 \%$ & $-1.88 \%$ & $-1.60 \%$ \\
\hline
\end{tabular}

Table 6: Layout of returns from the accounting units of the investment and pension funds within the framework of 1, 2 and 3 standard deviations (June 2011 - June 2014) 


\begin{tabular}{|c|c|c|c|c|}
\hline & Ilirika Global & $\begin{array}{c}\text { KB Mandatory } \\
\text { Pension Fund }\end{array}$ & $\begin{array}{c}\text { KB Publikum - } \\
\text { Balanced }\end{array}$ & KD South Balkan \\
\hline \multicolumn{5}{|c|}{ DEV + } \\
\hline $75 \%$ & $6.38 \%$ & $2.35 \%$ & $4.89 \%$ & $6.09 \%$ \\
\hline $89 \%$ & $9.80 \%$ & $3.28 \%$ & $7.30 \%$ & $9.33 \%$ \\
\hline \multicolumn{5}{|c|}{ DEV - } \\
\hline $75 \%$ & $-7.28 \%$ & $-1.39 \%$ & $-4.73 \%$ & $-6.85 \%$ \\
\hline $89 \%$ & $-10.69 \%$ & $-2.32 \%$ & $-7.14 \%$ & $-10.09 \%$ \\
\hline
\end{tabular}

Table 7: Layout of returns within 2 and 3 standard deviations from the accounting units of the investment and pension funds according to Chebyshev's equation in the absence of a normal schedule of distribution.

Table 6 and Table 7 offer the layout of returns from the accounting units of the investment and pension funds within the framework of 1,2 and 3 standard deviations with a normal schedule of distribution and with Chebyshev's equation in the absence of a normal schedule of distribution.

\begin{tabular}{|c|c|c|c|c|c|c|c|c|c|c|c|}
\hline & $\begin{array}{c}\text { lirika } \\
\text { Global }\end{array}$ & $\begin{array}{c}\text { Ilikika } \\
\text { Southeast } \\
\text { Europe }\end{array}$ & $\begin{array}{c}\text { Innovo } \\
\text { Status }\end{array}$ & $\begin{array}{c}\text { Koluntary } \\
\text { Pension } \\
\text { Fund }\end{array}$ & $\begin{array}{c}\text { Mandatory } \\
\text { Pension } \\
\text { Fund }\end{array}$ & $\begin{array}{c}\text { KB } \\
\text { Publikum } \\
\text { Balanced }\end{array}$ & $\begin{array}{c}\text { KB } \\
\text { Publikum } \\
\text { Bonds }\end{array}$ & $\begin{array}{c}\text { KD } \\
\text { BRIC }\end{array}$ & $\begin{array}{c}\text { KD } \\
\text { South } \\
\text { Balkan }\end{array}$ & $\begin{array}{c}\text { NLB } \\
\text { Penzija } \\
\text { plus }\end{array}$ & $\begin{array}{c}\text { NLB Nov } \\
\text { Penziski } \\
\text { Fond }\end{array}$ \\
\hline $\begin{array}{l}\text { Adjusted } \\
\text { Skewness }\end{array}$ & -1.1445 & -0.9112 & 0.5382 & 0.3177 & -0.8331 & -0.7352 & -0.2570 & -0.2420 & -1.1906 & -0.0316 & -0.5941 \\
\hline $\begin{array}{c}\text { Adjusted } \\
\text { Kurtosis }\end{array}$ & $\begin{array}{c}\text { Legative } \\
\text { Lepto- } \\
\text { kurtic }\end{array}$ & $\begin{array}{c}\text { Legative } \\
\text { kurtic }\end{array}$ & Positive & Positive & Positive & Negative & Negative & Negative & $\begin{array}{c}\text { Negativ } \\
\text { e }\end{array}$ & Negative & Negative \\
\hline
\end{tabular}

Table 8: Coefficients of the skewness and kurtosis of investment and pension funds in the Republic of Macedonia

As for the asymmetry of returns of accounting units from the funds, the observation is that almost all are negative and asymmetrical, meaning that they have "fat" tails towards extremely positive and negative values of the distributional curve. For the kurtosis, they are likewise leptokurtic, meaning that there is a risk of erroneously estimating the expected future returns.

\begin{tabular}{|c|c|c|c|c|c|c|c|c|c|c|c|}
\hline Sharpe & $\begin{array}{c}\text { Ilirika } \\
\text { Global }\end{array}$ & $\begin{array}{c}\text { Ilirika } \\
\text { Southeast } \\
\text { Europe }\end{array}$ & $\begin{array}{c}\text { Innovo } \\
\text { Status }\end{array}$ & $\begin{array}{c}\text { Voluntary } \\
\text { Pension } \\
\text { Fund }\end{array}$ & $\begin{array}{c}\text { Kandatory } \\
\text { Pension } \\
\text { Fund }\end{array}$ & $\begin{array}{c}\text { KB } \\
\text { Publikum } \\
\text { Balanced }\end{array}$ & $\begin{array}{c}\text { KB } \\
\text { Publikum } \\
\text { Bonds }\end{array}$ & $\begin{array}{c}\text { KD } \\
\text { BRIC }\end{array}$ & $\begin{array}{c}\text { KD } \\
\text { South } \\
\text { Balkan }\end{array}$ & $\begin{array}{c}\text { NLB } \\
\text { Penzija } \\
\text { plus }\end{array}$ & $\begin{array}{c}\text { NLB } \\
\text { Nov } \\
\text { Penziski } \\
\text { Fond }\end{array}$ \\
\cline { 2 - 11 } & -0.5848 & -1.0601 & -0.9186 & 1.3417 & 1.0864 & -0.0974 & 1.3465 & -0.3827 & -0.5689 & 1.1668 & 1.4210 \\
\hline
\end{tabular}

Table 9: Sharpe coefficients for the investment and pension funds in R. Macedonia

\begin{tabular}{|c|c|c|c|c|c|c|c|c|c|c|c|}
\hline \multirow[t]{2}{*}{ Sortino } & $\begin{array}{l}\text { Ilirika } \\
\text { Global }\end{array}$ & $\begin{array}{c}\text { Ilirika } \\
\text { Southeast } \\
\text { Europe }\end{array}$ & $\begin{array}{l}\text { Innovo } \\
\text { Status }\end{array}$ & $\begin{array}{c}\text { KB } \\
\text { Voluntary } \\
\text { Pension } \\
\text { Fund }\end{array}$ & \begin{tabular}{|c|} 
KB \\
Mandatory \\
Pension \\
Fund \\
\end{tabular} & $\begin{array}{c}\text { KB } \\
\text { Publikum } \\
\text { Balanced }\end{array}$ & $\begin{array}{c}\text { KB } \\
\text { Publikum } \\
\text { Bonds }\end{array}$ & $\begin{array}{l}\text { KD } \\
\text { BRIC }\end{array}$ & $\begin{array}{c}\text { KD } \\
\text { South } \\
\text { Balkan }\end{array}$ & $\begin{array}{l}\text { NLB } \\
\text { Penzija } \\
\text { plus }\end{array}$ & $\begin{array}{c}\text { NLB } \\
\text { Nov } \\
\text { Penziski } \\
\text { Fond }\end{array}$ \\
\hline & \begin{tabular}{|l|}
-0.7105 \\
\end{tabular} & -1.2753 & -1.7170 & 3.1749 & 1.7843 & -0.1156 & 2.9572 & \begin{tabular}{|l|}
-0.5749 \\
\end{tabular} & -0.6464 & 2.8686 & 3.5812 \\
\hline
\end{tabular}

Table 10: Sortino coefficients for the investment and pension funds in R. Macedonia

Table 9 and Table 10 illustrates that pension funds' have delivered a significantly positive volatility-adjusted risk premium in the analyzed period. 


\begin{tabular}{|c|c|c|c|c|c|c|c|c|c|c|c|}
\hline \multirow[t]{2}{*}{ Omega } & $\begin{array}{l}\text { Ilirika } \\
\text { Global }\end{array}$ & $\begin{array}{l}\text { Ilirika } \\
\text { Southeast } \\
\text { Europe }\end{array}$ & $\begin{array}{l}\text { Innovo } \\
\text { Status }\end{array}$ & $\begin{array}{c}\text { KB } \\
\text { Voluntary } \\
\text { Pension } \\
\text { Fund } \\
\end{array}$ & \begin{tabular}{|c|} 
KB \\
Mandatory \\
Pension \\
Fund \\
\end{tabular} & $\begin{array}{c}\text { KB } \\
\text { Publikum } \\
\text { Balanced }\end{array}$ & $\begin{array}{c}\text { KB } \\
\text { Publikum } \\
\text { Bonds }\end{array}$ & $\begin{array}{c}\text { KD } \\
\text { BRIC }\end{array}$ & $\begin{array}{c}\text { KD } \\
\text { South } \\
\text { Balkan }\end{array}$ & $\begin{array}{l}\text { NLB } \\
\text { Penzija } \\
\text { plus }\end{array}$ & \begin{tabular}{|c|} 
NLB \\
Nov \\
Penziski \\
Fond \\
\end{tabular} \\
\hline & 0.6340 & 0.4218 & 0.5237 & 2.4778 & 2.1019 & 0.9220 & 2.5577 & 0.7587 & 0.6125 & 2.1924 & 2.5460 \\
\hline
\end{tabular}

Table 11: Omega coefficients for the investment and pension funds in $R$. Macedonia

The omega ratios confirms the previous indices and presents positive values only in pension funds in terms of the likeness of achieving expected returns.

The line chart on the graphs below shows the trend of monthly income in the funds, while the chart area shows the continued loss of the funds during the analyzed period (per month). The table shows the maxdrawdown of the fund throughout the entire analyzed period.

\section{Ilirika Global}

\begin{tabular}{cc|}
\hline \multicolumn{2}{|c|}{ Results } \\
\hline Open & 57,26 \\
Close & 48,72 \\
Three Year Return & $-14,91 \%$ \\
Annualized Return & $-5,24 \%$ \\
Max Drawdown & $-22,28 \%$ \\
Max Drawup & $11,04 \%$ \\
Calmar Ratio & $-0,24$ \\
Sterling Ratio & $-0,20$
\end{tabular}

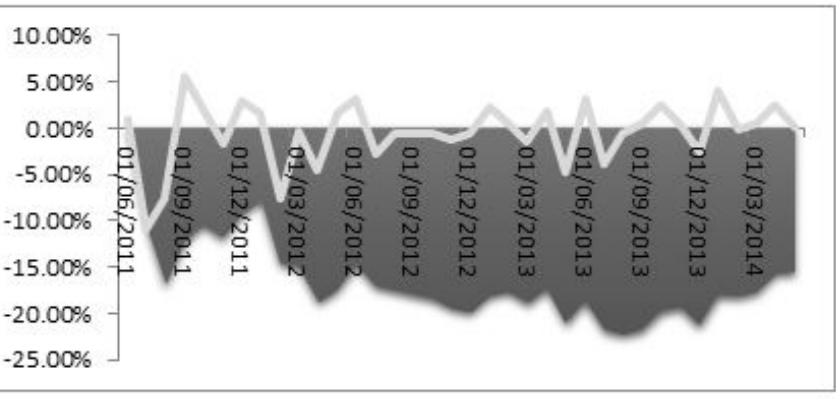

Ilirika Southeast Europe

\begin{tabular}{cc}
\hline \multicolumn{2}{|c|}{ Results } \\
\hline Open & 56,13 \\
Close & 39,31 \\
Three Year Return & $-29,96 \%$ \\
Annualized Return & $-11,19 \%$ \\
Max Drawdown & $-37,28 \%$ \\
Max Drawup & $12,08 \%$ \\
Calmar Ratio & $-0,30$ \\
Sterling Ratio & $-0,32$
\end{tabular}

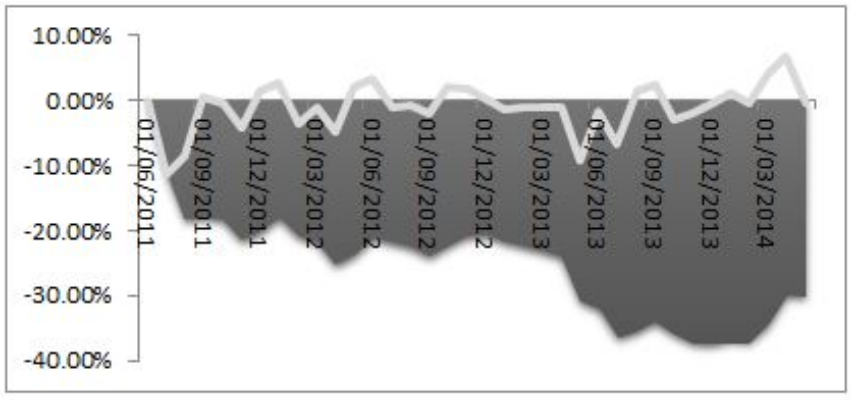

\section{Innovo Status Akcii}

\begin{tabular}{|cc|}
\hline \multicolumn{2}{|c|}{ Results } \\
\hline Open & 34,84 \\
Close & 28,77
\end{tabular}

Three Year Return - $-17,42 \%$

Annualized Return - $-6,18 \%$

Max Drawdown $\quad-23,57 \%$

Max Drawup $\quad 8,99 \%$

Calmar Ratio $\quad-0,26$

Sterling Ratio $\quad-0,23$

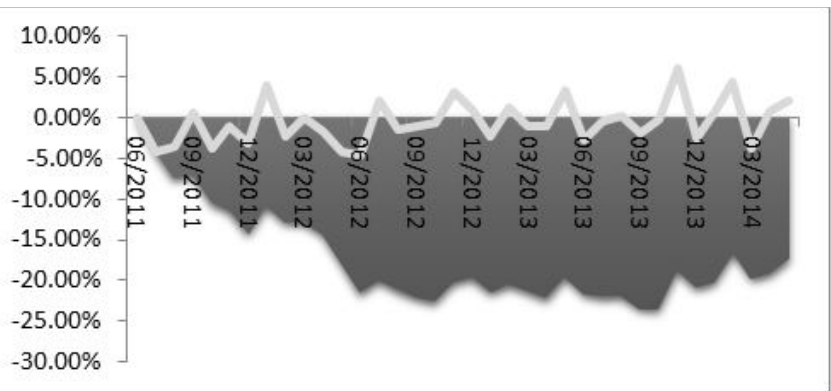


KB Voluntary Pension Fund

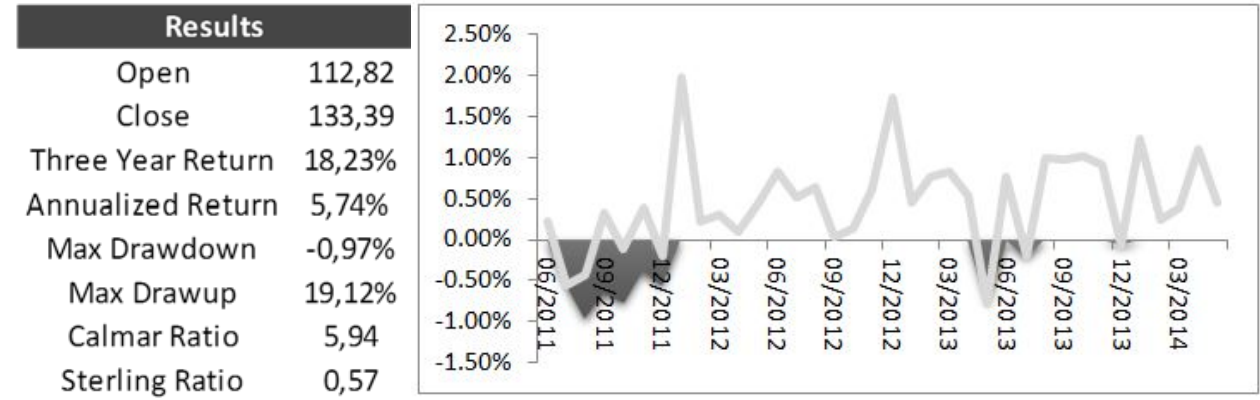

KB Mandatory Pension Fund

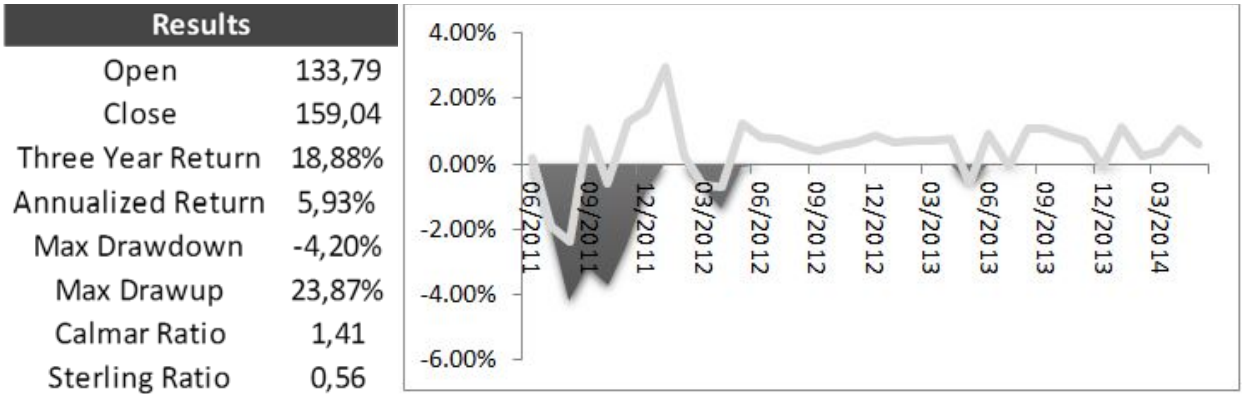

KB Publikum - Balanced

\begin{tabular}{cc|}
\hline \multicolumn{2}{c|}{ Results } \\
\hline Open & 101,40 \\
Close & 104,37 \\
Three Year Return & $2,93 \%$ \\
Annualized Return & $0,97 \%$ \\
Max Drawdown & $-16,45 \%$ \\
Max Drawup & $23,20 \%$ \\
Calmar Ratio & 0,06 \\
Sterling Ratio & 0,05
\end{tabular}

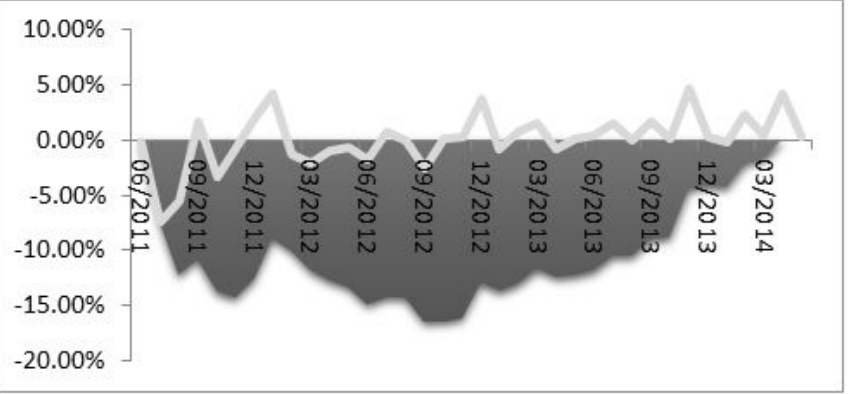

KB Publikum - Bonds

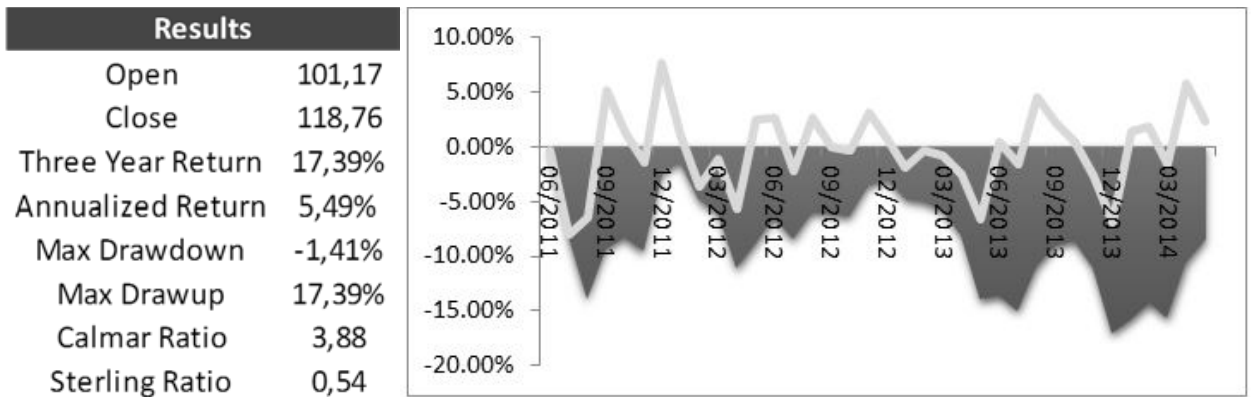


KD BRIC

\begin{tabular}{cc|}
\hline \multicolumn{2}{c}{ Results } \\
\hline Open & 150,87 \\
Close & 138,04 \\
Three Year Return & $-8,50 \%$ \\
Annualized Return & $-2,92 \%$ \\
Max Drawdown & $-17,09 \%$ \\
Max Drawup & $14,53 \%$ \\
Calmar Ratio & $-0,17$ \\
Sterling Ratio & $-0,16$
\end{tabular}

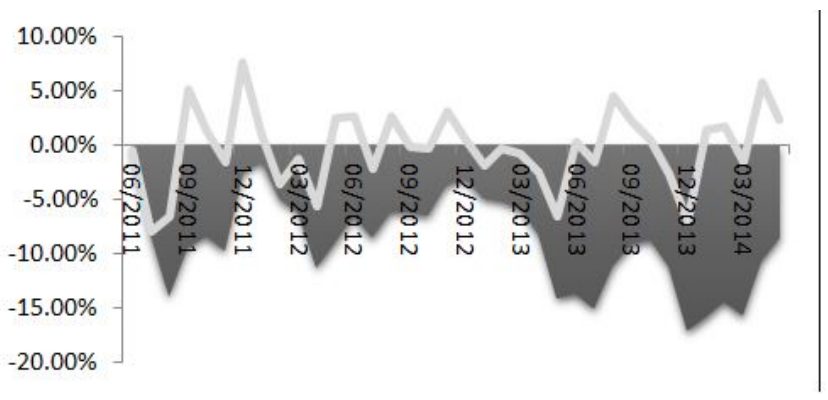

KD South Balkan

\begin{tabular}{cc|}
\hline \multicolumn{2}{c|}{ Results } \\
\hline Open & 123,47 \\
Close & 107,71 \\
Three Year Return & $-12,77 \%$ \\
Annualized Return & $-4,45 \%$ \\
Max Drawdown & $-31,95 \%$ \\
Max Drawup & $28,23 \%$ \\
Calmar Ratio & $-0,14$ \\
Sterling Ratio & $-0,13$
\end{tabular}

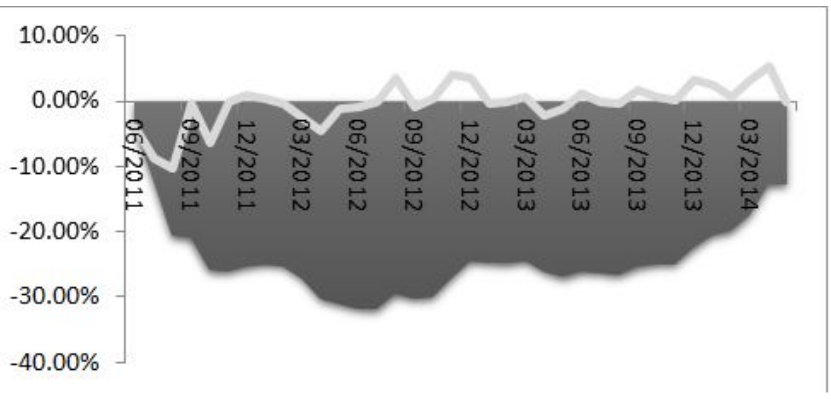

NLB Penzija plus

\begin{tabular}{cc|}
\hline \multicolumn{2}{|c|}{ Results } \\
\hline Open & 112,79 \\
Close & 133,28 \\
Three Year Return & $18,17 \%$ \\
Annualized Return & $5,72 \%$ \\
Max Drawdown & $-2,34 \%$ \\
Max Drawup & $21,00 \%$ \\
Calmar Ratio & 2,44 \\
Sterling Ratio & 0,55
\end{tabular}

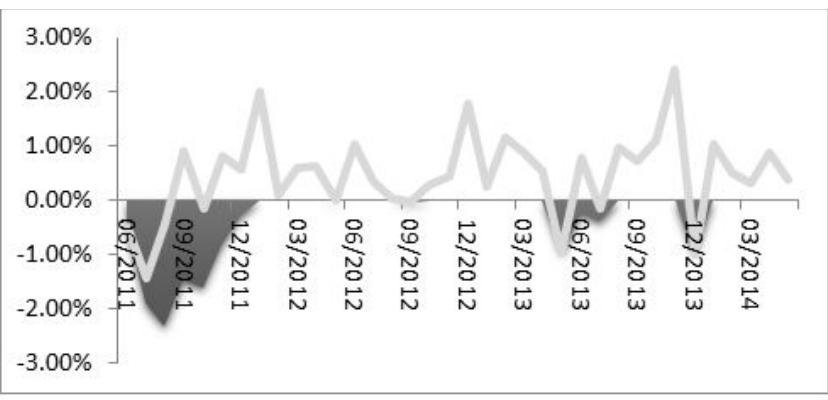

\section{NLB Nov Penziski Fond}

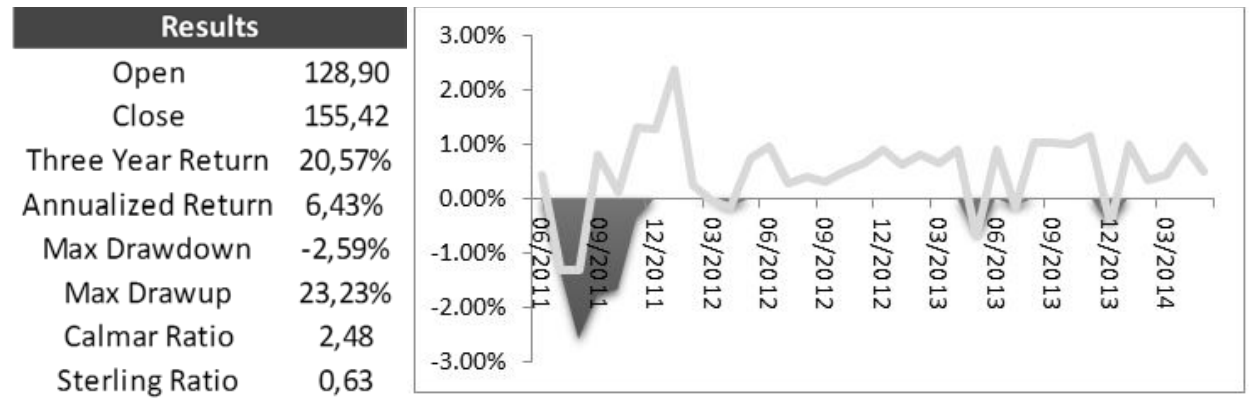

Figure 12-23: Calmar and Sterling Ratios of investment and pension funds from $R$. Macedonia (June 2011 - June 2014) 
The results show that the Calmar ratios based on data from a three-year series of monthly returns of the accounting unit from investment and pension funds is a good indicator of future downhill events. The bigger the coefficient, the lesser the possibility that the accounting unit will exhibit a downward slope. The KB Mandatory Pension Fund has good performance, NLB Penzija plus and NLB Nov Penziski Fond have solid performance, KB Publikum - Bonds has very good performance, while KB Voluntary Pension Fund has excellent performance of this indicator.

\section{Discussion and conclusion}

The analysis applied in this paper was conducted on monthly returns of investment and pension funds operating in the Republic of Macedonia (June 2011 - June 2014). It uses the basic, but still highly informative statistical characteristic moments like skewness, kurtosis, Jarque-Bera, and Chebyishev's Inequality. The objective of this study is trough analyses that use the above and other specific statistical techniques (Sharpe, Sortino, omega, upside potential, Calmar, Sterling) to draw relevant conclusions regarding the risks and the characteristic moments in the performances of the investment and pension funds in Macedonia.

Statistical analysis has shown that pension funds have delivered a significantly more positive volatility-adjusted risk premium than investment funds in the analyzed period.

This paper is the first part of a more comprehensive survey that should provide a complete picture of the performance of investment and pension funds in the Republic of Macedonia.

In the next part of the survey, a quantitative statistical analysis will be conducted which will focus on the indicators of relative risk (Up capture and Down capture ratio, Up number and Down number ratio, Up percentage and Down percentage ratio, Percentage gain ratio, Bias ratio and Hurst index). In addition, we will use the Merton-Henriksson and Treynor-Mazuy models to evaluate market-timing performance and stock-selection abilities of the investment and pension funds operating in the Republic of Macedonia.

\section{References}

[1] Bacon, C. (2000). How sharp is the Sharpe-ratio? - Risk-adjusted performance measures. Statpro White Paper.

[2] Bogdanovski V, Percinkova B. (2012). Optimal portfolio of securities listed on the Macedonian stock exchange. Faces of the crisis. EURM, 702-711.

[3] Khan, S. Calmar Ratio. http://investexcel.net/calmar-ratio/ [Accessed on 24 September 2014]. 
[4] De Wet, R, Krige, N. and Smit, E. (2009). Omega sharpens portfolio performance evaluation. USB Leaders Lab, 3(2), 12-16.

[5] Doane, D. P. and Seward, L. E. (2011). Measuring skewness: A forgotten statistic. Journal of Statistics Education, 19(2), 1-18.

[6] eVestment. Guide to investment statistics. https://www.evestment.com/resources/investment-statistics-guide [Accessed on 24 September 2014].

[7] Elton, E. J., Gruber, M. J., Brown, S. J. and Goetzmann, W. N. (2014). Modern Portfolio Theory and Investment Analysis. John Wiley \& Sons.

[8] Fabozzi, F. J. (Ed.). (1997). Pension Fund Investment Management (Vol. 25). John Wiley \& Sons.

[9] Hinz, R. P. (Ed.). (2010). Evaluating the Financial Performance of Pension Funds. World Bank Publications.

[10] Jarque, C. M., and Bera, A. K. (1987). A test for normality of observations and regression residuals. Revue Internationale de Statistique (International Statistical Review), 55(2), 163-172. doi:10.2307/1403192.

[11] Le Sourd, V. (2007). Performance Measurement for Traditional Investment. EDHEC publication, Nice.

[12] MAPAS. http://www.mapas.mk/mapas-en/index.php/mapas/about-mapas [Accessed on 15 January 2015].

[13] National Bank of the Republic of Macedonia. (July 2014). Financial stability report for the Republic Of Macedonia in 2013.

http://www.nbrm.mk/WBStorage/Files/WebBuilder_FSR_2013_ENG.pdf [Accessed on 15 January 2015].

[14] Plantinga, A., van der Meer, R. and Sortino, F. (2001). The impact of downside risk on risk-adjusted performance of mutual funds in the Euronext markets. Geneva Papers on Risk and Insurance, 1-14.

[15] Anicazna. Returns from the accounting units of the funds. http://www. anicazna.com/Fondovi [Accessed on 15 January 2015].

[16] Kaplan Schweser (2013). Schweser Notes for the FRM Exam 2013: Part 1: Book 2: Quantitative Analysis. Kaplan Schweser.

[17] Sortino, F. A., Van de Meer, R., Plantinga, A. and Forsey, H. (2003). The upside potential ratio: What are we trying to measure. Senior Consultant, 6(11).

[18] The Securities and Exchange Commission of the Republic of Macedonia. Authority and powers. http://www.sec.gov.mk/default.aspx?item=staticpages\&itemid=18 [Accessed on 15 January 2015]. 